\title{
Early Modern Ottoman Politics of Emotion: What Has Love Got to Do With It?
}

\author{
Nil Tekgül \\ Bilkent University \\ niltekgul@yahoo.com
}

\begin{abstract}
Despite a growing interest worldwide in the history of emotions, the topic has attracted the attention of scholars of Ottoman history only recently. In an attempt to understand the motivations underlying political undertakings, this article explores emotions, with a specific focus on mahabbet (love) and merhamet (compassion). It examines the social meaning attached to and the cultural importance of love and compassion in early modern Ottoman political language. I claim that as a socially constructed and political emotion, compassion was historically and culturally significant, serving as a tool to formulate political relations of domination and subordination.
\end{abstract}

\section{Keywords}

history of emotions - Ottoman history - Ottoman political thought - early modern mahabbet-merhamet-compassion

It is apparent that individuals are in need of socializing to achieve order and acquire happiness and perfection. Socializing, however, encompasses the mischief of hindering and striving to surpass the other. There are two paths to overcome this mischief. The first path is achieved by executing the rules of justice and upholding the authority of the Sultanate, as has already been shown. The second path is the path of love (mahabbet). 
If there exists love among the members of society, there is no need for justice. ${ }^{1}$

Kinalizade alí çElebí, Ahlak-i Ala $i$

In his book of ethics Ahlak-i Ala $i$, one of the most widely read and copied books of the early modern Ottoman world discussing political theory, ${ }^{2}$ the famous sixteenth-century Ottoman scholar Kınalızade Ali Çelebi (d. 1571) ranks mahabbet, which may roughly be translated into English as mutual love, higher than justice in terms of its importance as a principal instrument of control in achieving order. ${ }^{3}$ For a contemporary reader, considering love as a social and political emotion may seem counterintuitive. One might wonder, "What has love got to do with politics?" This question reveals an implicit assumption that emotions are innate and irrational and that they reside only in the private sphere of intimate relations; hence, politics should be devoid of any emotions and follow the principles of reason. ${ }^{4}$ Until recently, historians followed this dichotomy between reason and emotion, as well as assumed that emotions are universal without any change across time and place. Thus, despite the abundance of words, concepts, metaphors, and anecdotes about emotions in various sources, historians have neglected them in their search for explaining human behavior. However, for the past four decades, the universality of emotions

1 Koç, Mustafa (ed.), Kınalızade Ali Çelebi: Ahlak-ı Ala'i (Istanbul: Klasik, 2007), p. 413: "Çün zahir oldu ki efrad-ı insan intizam-ı ahval ve tahsil-i sa'adet ü kemal etmekte ictima' u téellüfe muhtac ve ictima u te'ellüf dahi mazarrat-ı müzahame vü mugalebeyi müştemildir Ve bu mazarratın def'i iki tarikle mutasavverdir: Birisi icra-yı kavanin-i adalet ve ihkam-ı saltanat u iyalettir ki işaret olundu... İkinci tarik tarik-i mahabbettir... Amma bir cema'at içinde tarik-i mahabbet olsa, mümkindir ve mahabbet olıcak tarik-i adalete ihtiyac kalmaz." The translations from Ahlak-i Ala $i$ and the archival sources belong to the author.

2 Ahlak-i Ala $i$ "was one of the 'bestsellers' of the Ottoman book market from the 16th to the 18th centuries. The Süleymâniye Library in Istanbul has 22 manuscript copies of this book; a single copier, Derviş Mehmet Ahlâkî, is known to have copied it 40 times in the late 16th century." Tezcan, Baki, "Ethics as a domain to discuss the political: Kınalızâde Ali Efendi's Ahlâk-ı Alât," in IRCICA International Congress on Learning and Education in the Ottoman World (Istanbul, 12-15 April 1999), Ali Çaksu (ed.) (Istanbul: IRCICA, 2001), p. 110. Hereafter, "love" will be used as the translation of "mahabbet".

In her comprehensive article, Catherine Lutz explores the unspoken assumptions embedded in the concept of emotion. She argues that "emotion is either assumed to be opposed to the positively evaluated process of thought, or to a negatively evaluated estrangement from the world. When we label someone as 'unemotional' we either mean that he/she is calm, rational, and deliberate, or he/she is uninvolved and alienated." Lutz, Catherine, "Emotion, thought and estrangement: Emotion as a cultural category," Cultural Anthropology, 1/3 (1986), 287-309. 
and the dichotomy between reason and emotion have been challenged by scholars of history, anthropology, and sociology.

Spearheaded by historians such as Peter Stearns, Barbara Rosenwein, and William Reddy, the field of the history of emotions has led to the development of new insights into human motivation and thus enriched our understanding of the past. ${ }^{5}$ They have convincingly shown that not only emotional norms, prescriptions, and linguistic expressions but also the experience of emotions themselves changes across time and space. Scholars of psychology and neuroscience such as Lisa Feldman Barrett, have further contributed to our understanding of emotions with their experiment-based research. In her theory of constructed emotions, emotions emerge as "a combination of the physical properties of our body, a flexible brain that wires itself to whatever environment it develops, and our culture and upbringing, which provide that environment."6 In other words, Barrett acknowledges not only the biological core systems in our brain and body but also the importance of our culture and past experiences in the process of constructing emotions. ${ }^{7}$ Indeed, the findings of both life sciences and social sciences confirm and complement one another, even if the focus and methods of these two fields are quite different.

This article does not intend to review the scholarship on the history of emotions. However, what is evident about the scholarship produced so far is that it is overwhelmingly European. ${ }^{8}$ Although new historical research is now available regarding the emotions of various societies across the world, such as

5 Although it is not possible to cite all the works, for some of the major studies see Boddice, Rob, The History of Emotions (Manchester: Manchester University Press, 2018); Idem, A History of Feelings (London: Reaktion Books, 2019); Plamper, Jan, The History of Emotions: An Introduction (Oxford: Oxford University Press, 2015); Reddy, William, The Navigation of Feeling: A Framework for the History of Emotions (Cambridge: Cambridge University Press, 2001); Idem, The Making of Romantic Love: Longing and Sexuality in Europe, South Asia and Japan, 900-1200 CE (Chicago: University of Chicago Press, 2012); Liliequist, Jonas (ed.), A History of Emotions, 1200-1800 (London: Pickering \& Chatto, 2012); Rosenwein, Barbara H., "Problems and methods in the history of emotions," Passions in Context: Journal of the History and Philosophy of the Emotions, 1 (2010), 1-32; Eadem, Emotional Communities in the Early Middle Ages (Ithaca: Cornell University Press, 2006); Eadem, "Worrying about emotions," American Historical Review, 107 (2002), 821-45; Stearns, Peter N. and Carol Z. Stearns, "Emotionology: Clarifying the history of emotions and emotional standards," American Historical Review, 90/4 (1985), 813-36.

6 Barrett, Lisa Feldman, How Emotions Are Made: The Secret Life of the Brain (New York: Houghton Mifflin Harcourt, 2017), p. xii.

7 Ibid., p. 33 .

8 For a comprehensive review of recent studies on the field, see Wiesner-Hanks, Merry, "Overlaps and intersections in new scholarship on empires, beliefs, and emotions," Cromohs (Cyber Review of Modern Historiography), 20 (2015-16), 1-24. 
Mexico, ${ }^{9}$ China, ${ }^{10}$ Russia, ${ }^{11}$ and Indo-Muslim societies, ${ }^{12}$ the relative scarcity of non-European research makes comparisons across societies difficult.

Despite a growing interest worldwide in the history of emotions, it has attracted the attention of scholars of Ottoman history only recently. ${ }^{13}$ Zeynep Yelçe, for example, has explored the norms of anger in pre-modern Ottoman courtly culture, particularly who gets to experience and display anger, when, why, toward whom, how, and to what extent, by using narratives of Tursun Beg's (d. 1490s) Tarih-i Ebu'l-Feth, Kemalpaşazade's (d. 1534) Tevarih-i Al-i Osman, Mustafa Ali's (d. 1600) Künhü'l-Ahbar, and Kınalızade's (d. 1571) Ahlak-i Ala $i i^{14}$ She argues that royal wrath was a tool of intimidation reinforcing the authority of the Sultan, and its expressions served as a warning and threat against possible opposition. Özizmirli15 and Dankoff, ${ }^{16}$ on the other hand, explore the narratives of fear and shame, respectively, in the travelogue of the

Villa-Flores, Javier and Sonya Lipsett-Rivera (eds), Emotions and Daily Life in Colonial Mexico (Albuquerque: University of New Mexico Press, 2014).

10 "Aspects of emotion in late imperial China" as a thematic issue of Asiatische Studien / Études Asiatiques, LXvi/4 (2012), 893-1001; Kutcher, Norman, "The skein of Chinese emotions history," in Doing Emotions History, Susan J. Matt and Peter N. Stearns (eds) (Urbana, Chicago: University of Illinois Press, 2014), pp. 57-73.

For a comment on Slavic emotions research, see Reddy, William M., "Emotional turn? Feelings in Russian history and culture: Comment," Slavic Review, 68/2 (2009), 329-34.

With regard to studies on Indo-Muslim societies, Margrit Pernau draws special attention with her research on emotions in nineteenth-century Indo-Muslim culture as well as with her effort to fruitfully combine the field of the history of concepts (especially Koselleck's view on the formation of concepts) with the history of emotions. See, for instance, Pernau, Margrit, "Introduction: Concepts of emotions in Indian languages," Contributions to the History of Concepts, 11/1 (2016), 24-37; Eadem and Imke Rajamani, "Emotional translations: Conceptual history beyond language," History and Theory, 55 (2016), 60.

13 Karateke, Hakan T., H. Erdem Çıpa and Helga Anetshofer (eds), Disliking Others: Loathing, Hostility, and Distrust in Premodern Ottoman Lands (Boston: Academic Studies Press, 2018); Afacan, Şeyma, "Of the soul and emotions: Conceptualizing 'the Ottoman individual' through psychology" (unpublished Ph.D. dissertation, University of Oxford, 2016); Yelçe, Zeynep N., "Royal wrath: Curbing the anger of the Sultan," in Discourses of Anger in the Early Modern Period, Karl Enenkel and Anita Traninger (eds) (Leiden and Boston: Brill, 2015), pp. 439-57; Andrews, Walter, "Ottoman love: Preface to a theory of emotional ecology," in A History of Emotions, 1200-180o, Jonas Liliequist (ed.) (London: Pickering \& Chatto, 2012), pp. 21-48; Andrews, Walter G. and Mehmet Kalpakli, The Age of Beloveds: Love and the Beloved in Early-Modern Ottoman and European Culture and Society (Durham: Duke University Press, 2005); Dankoff, Robert, "Ayıp değil! (No disgrace!)," Journal of Turkish Literature, 5 (2008), 77-90; Özizmirli, Görkem, "Fear in Evliya Çelebi's Seyahatname: Politics and historiography in a seventeenth century Ottoman travelogue" (unpublished M.A. thesis, Koç University, 2014).

14 Yelçe, "Royal wrath," p. 442.

15 Özizmirli, "Fear in Evliya Çelebi's Seyahatname."

16 Dankoff, “Ayıp değil!!” 
seventeenth-century Ottoman traveler Evliya Çelebi. Andrews demonstrates "how the idea of love can be used to describe one, possibly central feature of an Ottoman emotional ecology."17 Using literary genres, such as poetry, and exploring the cultural symbols inherent in them, he claims that "a particular notion of love was indeed central to the ways in which Ottoman society understood and scripted the emotional content of a broad range of primary relations: for example, parent-child, lover-beloved, friend-friend, patron-client, studentteacher, employer-employee, master-servant, spiritual adept-disciple, courtierruler, believer-God, etc."18 All of these studies are valuable contributions to the field, but they mainly use literary sources in their analyses. Although not directly but rather implicitly referring to emotions, an article by Marlene Kurz should also be noted, as it scrutinizes the main concepts of Ottoman state ideology and the concept of authority, focusing on the moral obligations of Ottoman rulers and subjects. ${ }^{19}$

Interest in emotions usually disappears when the topic turns to political history. Numerous valuable works on Ottoman political thought exist, starting with the seminal works of Halil İnalcık, ${ }^{20}$ which enrich our knowledge of how Ottomans at different times understood, implemented, and manipulated several political concepts. ${ }^{21}$ Although exclusion of emotions is common in their

17 Andrews, "Ottoman love."

18 Ibid., p. 21.

19 Kurz, Marlene, “Gracious Sultan, grateful subjects: Spreading Ottoman imperial 'ideology' throughout the empire," Studia Islamica, 107 (2012), 96-121.

20 İnalcık, Halil, Osmanlida Devlet, Hukuk, Adalet (Istanbul: Eren, 2005); Idem, "Osmanlı padişahı," Ankara Üniversitesi Siyasal Bilgiler Fakültesi Dergisi, 13/4 (1958), 68-80; Idem, "State and ideology under Sultan Süleyman I," in Idem, The Middle East and the Balkans under the Ottoman Empire: Essays on Economy and Society (Bloomington: Indiana University Press, 1993), pp. 70-94.

21 For a comprehensive and critical analysis, see Yılmaz, Hüseyin, "Osmanlı tarihçiliğinde Tanzimat öncesi siyaset düşüncesine yaklaşımlar," Türkiye Araştırmaları Literatür Dergisi, 1 (2003), 231-98. Gottfried Hagen has analyzed comprehensively the concept of "world order" (nizam-ı alem), which served as an underlying principle of the Ottoman discourse of legitimacy within the wider discourse of justice. Hagen, Gottfried, "Legitimacy and world order," in Legitimizing the Order: The Ottoman Rhetoric of State Power, Hakan T. Karateke and Maurus Reinkowski (eds) (Leiden and Boston: Brill, 2005), pp. 55-85; Idem, "The order of knowledge, the knowledge of order: Intellectual life," in The Cambridge History of Turkey. Vol. 2: The Ottoman Empire as a World Power, 1453-1603, Suraiya N. Faroqhi and Kate Fleet (eds) (Cambridge: Cambridge University Press, 2013), pp. 407-56. See also Karateke, Hakan T. and Maurus Reinkowski (eds), Legitimizing the Order: The Ottoman Rhetoric of State Power (Leiden and Boston: Brill, 2005); Darling, Linda T., A History of Social Justice and Political Power in the Middle East: The Circle of Justice From Mesopotamia to Globalization (New York: Routledge, 2013); Sariyannis, Marinos, Ottoman Political Thought up to the Tanzimat: A Concise History (Rethymno: Institute for Mediterranean Studies, 
narratives, the deliberate use of words denoting emotions is clearly reflected in primary sources. The simultaneous use of Arabic, Persian, and Turkish emotion words may be regarded as the source of this rich vocabulary, and this shows that Ottomans themselves were quite concerned with emotions.

This article attempts to grasp the fundamental social assumptions and negotiations underlying early modern Ottoman political relations by considering emotions. It thus traces the emotions found in the political language of the early modern Ottoman state, with a specific focus on mahabbet (love) and merhamet (compassion). The first section explores what Kinalızade calls "the path of love" (tarik-i mahabbet) in Ahlak-i Ala'i, which may be considered prescriptive. It prescribes the norms of early modern Ottoman society toward the emotion of love as reflected in the political relations between the Ottoman ruler and his subjects. The second section looks at another genre, archival sources, and traces linguistic expressions of compassion to understand the social meaning attached to and the cultural importance of the term. Linguistic expressions of compassion are contextualized in their respective historical settings, and the sequential order from the expression of an emotion to certain modes of behavior is traced. By drawing on imperial decrees and kadı court registers, I claim that as a socially constructed and political emotion embedded in early modern Ottoman political language, compassion was historically and culturally significant. It also acted as a tool to create state ideology, formulate political relations of domination and subordination, legitimize the political undertakings of rulers, and justify the political claims of subjects. The findings of this study are hoped to contribute to a deeper understanding of the motivations of political actors.

\section{The Path of Love in Kınalızade's Ahlak-i Ala $i$}

Shahab Ahmed argues that Muslims had tended historically to discuss political theory, the subject of how Muslims should govern their collective affairs in a polity, mostly under the conceptual canopy of ahlak. ${ }^{22}$ The seminal work in

2015); Idem, with a chapter by E. Ekin Tuşalp Atiyas, A History of Ottoman Political Thought up to the Early Nineteenth Century (Leiden and Boston: Brill, 2019).

22 Ahmed, Shahab, What is Islam? The Importance of Being Islamic (Princeton: Princeton University Press, 2015), p. 462. For ahlak texts, also see Alam, Muzaffar, The Languages of Political Islam: India, 1200-180o (Chicago: University of Chicago Press, 2004). Alam argues (p. 11) that ahlak texts represent the best example of the appropriation into the medieval Muslim intellectual world of non-Islamic ideas and they provide a philosophical, nonsectarian, and humane solution to emergent problems. However, ahlak texts were one 
this genre was the book of Nasreddin Tusi (1201-74), the Ahlak-i Nasiri, which served as a model for all subsequent ahlak texts. Indeed, Tusi was commissioned to translate Ibn Miskawayh's (ca. 932-1030) Tezhibü'lAhlak (Refinement of Ethics) from Arabic; but his work eventually turned into much more than a translation. ${ }^{23}$ The first part of Ahlak-i Nasiri was a summary arranged in a new way of Miskawayh's Tezhib, to which Tusi added two new parts; one on the household and family management, and another on politics. ${ }^{24}$ One of the most important influences on ahlak texts was Aristotle's Nicomachean Ethics, which was known to the Muslim world through translations and adaptations since the tenth century from the first adaptation by Ibn Miskawayh's Tezhibül Ahlak. ${ }^{25}$ Over the course of the half millennium after Tusi's death, his work was routinely paraphrased and elaborated upon in discussions on the relation of the ruler to law-making. ${ }^{26}$ After Tusi, the same tradition continued with Celaleddin Devvani's (1422-1506) Ahlak-i Celali and later with Kınalızade's Ahlak-i Ala $i{ }^{27}$ Like his predecessors, Kinalızade was in dialogue with philosophers such as Aristotle, Plato, and Galenus, and extensively referred to Farabi and the Sufi philosopher Al-Ghazali (d. 1111), making use of several literary sources, such as the famous Persian poet Sadi's Gülistan and Bustan and the poems of Rumi and Hafiz. ${ }^{28}$ The legacy of its predecessors is apparent in Ahlak-i Ala $i$, but Kinalızade synthesizes the ancient traditions and works of his predecessors in his own understanding of man and society; therefore, his work should be analyzed within its own historical context. The popularity of Ahlak-i Ala $i$ is

trend among many others in Islamicate political thought and thus other sources, including moralist treatises, historiographical works, copybooks of protocol and official correspondence, administration manuals, literary works, treatises on theology and kalam, collections of legal opinions (fetvas), encyclopedic works, also discuss political theories; Sariyannis, Ottoman Political Thought up to the Tanzimat, p. 12. Alam, The Languages of Political Islam, p. 47.

24 Ibid.

25 Pernau, Margrit, "Male anger and female malice: Emotions in Indo-Muslim advice literature", History Compass, 10/2 (2012), p. 121.

26 Ahmed, What is Islam?, p. 462.

27 For a detailed analysis of Miskawayh, Tusi, Devvani and Aristotle's influence on Kınalızade's Ahlak-i Ala'i showing similarities and differences between them see Tezcan, Baki, "The definition of sultanic legitimacy in the sixteenth century Ottoman Empire: The Ahlâk-ı Alâ'î of Kınalızâde Alî Çelebi (1510-1572)" (unpublished M.A. thesis, Princeton University, 1996). I am thankful to Baki Tezcan for sharing his unpublished thesis with me. Besides the unpublished thesis of Baki Tezcan (n. 27 above), for works exclusively on Ahlak-i Alai, see Okyay, Ayşe Sıdıka, Kınalızade Ali Efendi ve Ahlak-i Alai (Istanbul: İz Yayıncılık, 2011); Unan, Fahri, İdeal Cemiyet İdeal Devlet İdeal Hükümdar (Ankara: Lotus, 2004); Koç, Mustafa (ed.), Ahlak-i Ala'i (Istanbul: Klasik, 2007); and Öztürk, Hüseyin, Kınalızde Ali Çelebi'de Aile Ahlakı (Ankara, 1991). 
evident, especially between the sixteenth and eighteenth centuries; this may have happened for several reasons. Baki Tezcan, for example, argues that Ahlak-i Ala $i$ laid down the theoretical foundations of the compartmentalization of social order used by the succeeding Ottoman writers of advice literature. ${ }^{29}$ It could as well have been popular because it provided a more holistic view of politics starting from the ethics of an individual, followed by and intertwined with the governance of a household and the governance of any political organization. Kinalızade's work certainly exemplifies a wider circle of contemporary and later writers of political thought.

Kınalızade issued his work in three volumes: knowledge of ethics (ilm-i ahlak), knowledge of household management (ilm-i tedbiril-menzil), and knowledge of polity management (ilm-i tedbiril-medine). Kinalızade's main concern was the achievement and sustainability of political order in what he calls a virtuous city. Perfection and completion, for Kinalızade, required knowledge of ethics on each of three levels - personal, social, and political — which are viewed as intertwined and interdependent with one another. ${ }^{30}$ Kinalızade believes that the physical health of citizens should be in balance; hence, he presents a Galenic understanding of the four humors applied to the personal level. ${ }^{31}$ The relations among household members, community members, and those between the ruler and the ruled should rest on justice and harmony, representing the social and political levels.

The essence of order in its political context is referred to by Kinalızade as "executing the rules of justice and upholding the authority of the Sultanate."32 But immediately afterwards, he suggests another way, which he ranks even higher than justice, namely, "the path of love" (mahabbet), the related text of which is given in the introductory section. Mahabbet may roughly be translated into English as mutual love, affection, or friendship, and it is differentiated from passionate love ('aşk). Although the main theme of his work is justice and harmony in society, Kınalızade highlights love, the absence of which demands

29 Tezcan, "Ethics as a domain to discuss the political," p. 110.

30 For interdependence of the personal, social, and political in ahlak texts, see Pernau, Margrit, "Love and compassion for the community: Emotions and practices among North Indian Muslims, c. 1870-1930", The Indian Economic and Social History Review, 54/1 (2017), 21-42; Eadem, "From morality to psychology: Emotion concepts in Urdu, 1870-1920", Contributions to the History of Concepts, $11 / 1$ (2016), 38-57.

31 On the use of Galenic medicine by Italian and Islamic writers as a common frame of reference in their quest for the means of upholding a cohesive and well-regulated society, see Syros, Vasileios, "Galenic medicine and social stability in early modern Florence and the Islamic empires", Journal of Early Modern History, 17 (2013), 161-213.

32 Koç (ed.), Ahlak-i Ala'i, p. 413: "icra-yı kavanin-i adalet ve ihkam-ı saltanat u iyalettir ki işaret olundu." 
justice. In other words, it is basically the absence or the distortion of love that makes people demand justice; Kinalızade gives examples of distorted love.

In a lenghty chapter on love, ${ }^{33}$ Kinalızade defines its different kinds, which vary in their intensity and in the motives underlying the relations between several superior-subordinate relationships, such as God-the believer, father-son, husband-wife, and ruler-subjects. He states that love is of two sorts: natural and voluntary. While the love of a mother for her child is natural, the love of a novice for his/her master is considered an example of the voluntary kind. ${ }^{34} \mathrm{He}$ then continues by classifying voluntary love into four subforms in terms of their durability: "the one that is swift to contract and dissolve, the one that is slow to contract but swift to dissolve, the one that is swift to contract and slow to dissolve, and the one that is slow to contract and to dissolve."35 The ideal form is signified as that which is swift to contract and slow to dissolve. Furthermore, he defines the motives underlying love as pleasure (lezzet), benefit (nef'), and the good (hayr). ${ }^{36}$

In Kınalızade's virtuous city, where order is established, hayr is the motive behind the noblest and highest love, with no underlying material or other expectations from others and which is swift to contract and slow to dissolve. It mirrors the term fi-sebilillah, used in Ottoman daily language, which means "in the name of God" or "for God's sake," with no expected compensation. Love with a motive of pure good is further divided into four types. The first one is love for God, the source of which is goodness and happiness. The second one is love for one's own master, as masters teach righteous behavior and good ethics. The third one is love for one's parents and ancestors because they are the reason for one's existence and the source of one's values, either inherited from or taught by them. The fourth is love of a subject for his/her ruler. For some people, the last one ranks even higher than a son's love for his father. ${ }^{37}$

However, for Kınalızade, deviations from the ideal always exist. Love which is not induced by pure good requires the implementation of justice. He gives

33 Tezcan argues that although this section on love is placed within the political part of the book by Kınalızade, as well as by Devvani and Tusi, it was originally part of Miskawayh's Tezhibü'l Ahlak. Tezcan's comparision of the three texts shows that Kinalızade closely follows Tusi and Devvani in his discussion of love. Tezcan, "The Ahlâk-ı Alâ'î of Kınalızâde Alî Çelebi", pp. 94-95.

Koç, (ed.), Ahlak-ı Ala'i, p. 415:“Amma insanda olan mahabbet iki nev'dir: Biri tabi'i, biri iradidir: Tabi'i, maderin ferzendine mahabbeti gibi. Mahabbet-i iradi, mütéallimin muallimme, müridin şeyhine mahabbeti gibi." Ibid.

36 Ibid.: "Ve sebeb-i mahabbet dahi üç nesnedir. Evveli lezzet, ikincisi nef', üçüncüsü hayrdır." 
several examples of relations in which either the motivation of one party is different from that of the other or the sources consist solely of pleasure and benefit. He states the following:

If one party's love is induced for pleasure while the other's is for benefit, the relation would incur complaints and reprimand, and that is why this kind of love is termed "reproachful love" (mahabbet-i levvame). If [the] love between the Sultan and his subjects, the rich and the poor, the servant and the served belongs to this type, the relation may not be free of complaints and oppression, since both parties would want to benefit from the other. The oppression and complaints of the one who is being served would demand continuous service. ${ }^{38}$

In another section, Kınalızade explains the reasons for a subject's submission:

The source of love of subjects for their ruler may be to obtain their prosperity through the Sultan's benevolence and favors. Love and loyalty of subjects for those rulers who do not oppress and transgress is apparent. It is especially apparent for those Sultans who decorate their crown of wisdom with good government. If the Sultan conjoins this with justice and kindness, refrains from oppression, unites with his subjects in their faith, protects the weak, and is a friend of dervishes, subjects' love would transcend simple love (mahabbet) and reach a deeper level of love (meveddet), and they would become as submissive to their Sultan as are God's slaves. ${ }^{39}$

38 Ibid., pp. 428-29: "Bir tarafdan menfa'at, aherden lezzet sebebi olan mahabbete şekva vü itab çok olur... Ve bu makule mahabbete "mahabbet-i levvame" derler, levmden hali olmadığı için. Ve padişah u rai'yyet ve gani vü fakir ve hadim ü mahdum aralarında mahabbet bu kısmdadır. Şekva ve tazallümden hali değildir, zira her biri aherden bir nev‘ menfa'at ister. Muradı üzere olmıycak şekva vü tazallüm zahir olur. Ve adalet ri'ayet olmayınca bu şekva vü tazallüm mürtefi‘ olmaz. Mahdum, hadimden hidmette devam ve hazrette kıyam ve ihmal ü tekasülden gayet ictinab ve fehm-i garaz ve tahsil-i meramda nihayette ihtimam ister. Hadim riayet-i méakil ü melabis ü merakibinde nihayet-i inayet tama' eder."

39 Ibid., p. 431: "Re'ayanın selatine mahabbeti saye-i inayetlerinde müreffehü'l hal ve fevazıl-ı in‘amlarından müna‘amü'l-bal oldukları içindir. Ve selatin—ki ifrat-ı cevr ü zulmle mevsuf olmayalar—re'ayadan anlara ifrat-ı mahabbet ve nihayet-i sadakat mukarrerdir, hususen ki bir nesl-i şerif nice zeman vilayetde tac-ı hikmetlerini gevher-i hükumetle murassa ${ }^{a}$ etmiş ola. Eğer, ziver-i adl ü insafla ittisaf ve mezheb-i zulm ü i'tisaftan inhiraf edip mezheb-i hakk ri'ayetinde re'ayasıyla hem-kiş ve zu'afa-yı zir-destlerini hıfz u hiraset edip mu'in-i gani ve muhibb-i derviş ola, mahabbet dayiresinden geçip sıdk-ı rıkıyyet ü meveddet mertebesini koyup hakk-ı ubudiyyet üzere olurlar." 
In its normative and idealized form, then, subjects' submission to their rulers, as Kinalızade highlights, should mirror their love of God, as if they were God's slaves. In such cases, subjects' love reaches the level of meveddet, which also means love but apparently denotes a different and a deeper one.

Kinalızade's text shows not only the expected moral behavior of rulers and subjects in his virtuous city, in which political order has been achieved, but also the expected emotion, namely, love, to be felt and displayed by political actors toward one another, although not with the same intensity and in the same manner. In this sense, it mirrors a part of "emotionology," a term coined by Peter Stearns, one of the prominent scholars in the field of history of emotions. According to Peter and Carol Stearns, emotionology is defined as "the attitude or standards that a society, or a definable group within a society, maintains toward basic emotions and their appropriate expression; ways that institutions reflect and encourage these attitudes in human conduct." ${ }^{\prime 0}$ As a part of emotionology, in an idealized political order, the motive underlying love was therefore expected to be pure good for both parties, the absence of which would necessitate justice. The emotion of love was codified in this reciprocal relationship between the superior and the subordinate so as to mirror the relationship between God and a believer. Indeed, emotions were central not only to the Ottoman Empire but to all early modern monarchies. They constituted the basis of the relations between rulers and subjects in early modern monarchies because the fatherly love of the ruler to his subjects mirrored God's love of His believers; subjects and believers had a reciprocal duty to love God and their ruler. ${ }^{41}$

However, norms need to be congruent and consistent with everyday politics in order to have a pervasive, persuasive, and long-term impact on the meaningmaking mechanisms of the subjects. Without understanding whether and how normative behaviors have actually been practiced in politics, advice literature remains imaginary and insufficient, if not supplemented by other sources. The next section therefore explores the emotion of compassion in archival sources as a reflection of the path of love. In contrast to the normative characteristics of ahlak literature, this genre elaborates how concepts of emotions functioned in the political negotiations of daily life, as it allows us to trace the sequential link from expressions of emotions to the behaviors of historical actors within different contexts.

$40 \quad$ Stearns and Stearns, "Emotionology," p. 813.

41 Watanabe-O'Kelly, Helen, "Monarchies", in Early Modern Emotions: An Introduction, Susan Broomhall (ed.) (London and New York: Routledge, 2017), pp. 179-82. 


\section{Protection with Compassion}

A decree dated May 5, 1637 is anything but unique in depicting some of the central themes of early modern Ottoman political language. ${ }^{42}$ According to the decree, the Sultan had heard that his subjects were being oppressed and transgressed (zulm ve teaddi) by his delegated agents who exercised the Sultan's executive and judicial power. Indeed, the Sultan issued the decree with the aim to undertake political action in order to protect his subjects from the delegated agents' oppression and transgression. İnalcık defines adalet (justice) as the prevention and elimination of oppressive acts, zulm, by those who exercise power in the name of the ruler. ${ }^{43}$ In this political understanding, İnalcık adds, justice is not simply a principle of equity and imperial judgment but also a principle of social action ${ }^{44}$ that, in this case, requires strict measures against the ruler's agents in order to protect subjects. ${ }^{45}$

As understood from the same decree, the Sultan, after having heard that his subjects are being oppressed, makes the following statement: "My subjects are entrusted to my safekeeping by the Almighty Creator (reaya ki, vedayi-i Halik-i Kibriyadır) [and thus should be protected]."46 The reaya in such phrases denote all subjects regardless of their religious, ethnic, occupational, or other standings. Moreover, it was not only the ruler who was obliged to protect the subjects, but also his agents, who represented his executive and judicial powers,

42 İnalcık, Halil, "Adaletnameler," in Idem, Osmanlida Devlet, Hukuk, Adalet (Istanbul: Eren, 2005), pp. 142-44. The decree is addressed to judges representing the Sultan's judicial authority and to slaves of the Porte in the provinces representing his military and executive power. It is published by İnalcik in Arabic script, and is to be found in the Register of Important Affairs (mühimme defteri) no. 37, p. 74, document no. 186.

43 Inalcık claims that the prevention and elimination of oppressive acts was achieved by the Ottoman divan-ı hümayun (Imperial Council) functioning as the supreme court with a constant check and spying on the governors, punishments under the siyasa laws, the periodic promulgation of adaletnames (rescripts of justice) and by the arz-ı mahzar (petition) right of the subjects against the abuses of power of the public agents. İnalcık, "State and ideology," p. 71 .

44 Ibid.

45 Adalet, as a concept having a crucial importance in understanding the political structure of Middle Eastern states, has been the subject of many studies. See, for example, İnalcık, "Adaletnameler;" Unan, İdeal Cemiyet; Darling, A History of Social Justice and Political Power in the Middle East; Öz, Mehmet, "Klasik dönem Osmanlı siyasi düşüncesi: Tarihi temeller ve ana ilkeler," İslami Araştırmalar, XII /1 (1999), 27-39; Ergene, Boğaç A., "On Ottoman justice: Interpretations in conflict (1600-1800)", Islamic Law and Society, 8/1 (2001), $5^{2-87}$.

46 İnalcık, "Adaletnameler," p. 143. In other rescripts of justice, the phrase is also written as "reaya ki, vedayi-i Halikü'l berayadır...," meaning "my subjects are entrusted to my safekeeping by the Creator of all mankind." 
were expected to protect the Sultan's subjects in exactly the same way. In the concluding section of the decree, the Sultan threatens his agents that those who act otherwise would be severely punished and vehemently insulted. ${ }^{47}$ The threat then is extended to also include other officials, stating that this punishment was required for the purpose of admonition to these individuals and as an advice to many others. ${ }^{48}$ In this understanding, subjects, having been entrusted by the Almighty Creator to the Sultan, had to be protected against oppression, which denotes justice.

The protection of subjects, regardless of their secondary identities, stands as a recurrent and central theme of imperial decrees. The superior-subordinate relationship between the ruler and his subjects is usually explained by the metaphor of a shepherd as the protector of his flock in the scholarship that is based on ancient Indo-Persian theories of governance. However, explaining the willing obedience of subjects to their ruler within this model seems inadequate.

Donileen Loseke's terminology of symbolic codes seems more suitable as an analytical tool to explore the relationship between the Ottoman ruler and his subjects. According to Loseke, symbolic codes are "historically and culturally situated, socially circulating, complex interlocking systems of ideas about how the world works, how it should work, of the rights and responsibilities and normative expectations of people in the world." ${ }^{\prime 9}$ They function as cultural ways of thinking, encouraging people to think in a particular way that is shared in common. Likewise, the main determinant of the reciprocal relationship between the Ottoman ruler and his subjects was the symbolic code of protection denoting a particular cultural way of thinking. In other words, in their understanding of state and society, in terms of rights and responsibilities, the mutual relationship between rulers and subjects demanded the ruler to be a just leader who protects his subjects, whereas the ruled, as loyal subjects, had a right to such protection.

The same decree then goes as follows: "you [as my delegated agents] should manifest abundant clemency and tenderness and profuse generosity and

47 Ibid.: "bundan sonra reayaya ve fukaraya ümeradan ve gayriden cevr ve teaddi ve zulm ve te'ezzi olunduğu istima' oluna her ahval sizden bilinüb, ve bir vechle özrünüz makbul ve cevabınız mesmu' olmayub eşedd-i hakaret kızgınlık ile haklarınızdan gelinmek mukarrerdir".

48 Ibid.: "sairlere muceb-i ibret ve nicelere sebeb-i nasihat."

49 Loseke, Donileen R., "Examining emotion as discourse: Emotion codes and presidential speeches justifying war," The Sociological Quarterly, 50/3 (2009), p. 500. These systems of meaning are also named as "semiotic codes," "interpretive codes," or "symbolic repertoires." 
compassion to [my] subjects." ${ }^{50}$ The legitimacy of the ruler depended on the accomplishment of the obligation not only to protect, as a part of the symbolic code, but also to do so with compassion, which, according to Loseke's terminology, represents an emotion code accompanying the symbolic code. Emotion codes are defined as "sets of ideas about what emotions are appropriate to feel when, where, and toward whom or what as well as how emotion should be outwardly expressed." ${ }^{51}$ Protection in the political language of the early modern Ottoman state was always accompanied by the emotion code of compassion, merhamet, denoting a cultural way of feeling. The word merhamet is a complex and broad concept, linked in meaning with other words that cluster around it and enrich its conceptual meaning. It is also distinctive in allowing us to understand the relationship between the Ottoman state and its subjects. Merhamet was sometimes used synonymously with words such as tenderness (şefkat), benevolence (atıfet), grace (inayet), clemency (refet), munificence (mürüvvet), beneficence (mekremet), and generosity (fütürvet). We frequently encounter similar phrases in decrees ordering "to care for the well-being of the subjects purely on account of compassion and tenderness" 52 or "to treat subjects with tenderness and those who are needy of protection with compassion."53 The words fukara (pl. of fakir) and zuefa (pl. of zaif) literally mean the poor and the weak, respectively. However, in Ottoman political language, these should be understood not to denote material poverty or physical weakness, but rather, as Kurz rightly suggests, defenselessness and, therefore, dependence on the protection of the ruler and his agents. ${ }^{54}$

In the same decree, Bayram Paşa, the new grand vizier, is praised by Sultan Murad IV (1623-40) and introduced as one who "most illustriously guides the path to world order" (müşir-i efhamu nizami'l-alem), "prudently manages

5o İnalcık, "Adaletnameler," p. 143: "reaya ki, vedayi-i halik-i kibriyadır, haklarında mezid refet ve şefkat ve vufur-ı mekremet ve merhametim zuhura getürdüb."

$5^{1}$ Loseke, "Examining emotion as discourse," p. 500. They are also named "emotion schemas," "emotionologies," or "emotional cultures."

52 "reayaya mahz-ı merhamet ve şefkat içün...".

53 "reayaya şefkat ve fukara ve zuefaya merhamet ile hareket eyleyub..." See, for example, the rescript of justice dated February 1537, which refers to the new imperial subjects of Baghdad after it has been conquered: "feth olunmuş vilayet olmağın, anda vakii olan reayaya mezid himmet ve atıfet ve kemal-i şefkat ve merhametten..." (since [Baghdad] is one of the districts that we have conquered, the subjects living there [in Baghdad] should be treated with utmost benevolence, tenderness and compassion...); İnalcık, "Adaletnameler," pp. ${ }^{174-75}$.

54 Kurz, "Gracious Sultan, grateful subjects," p. 102. Similarly, the word gureba (pl. of garib), which literally means (i) strangers, people away from home, and (ii) the poor and the destitute, also denotes those who are in need of protection. 
important public affairs with his brightly shining ideas" (müdebbiru umuri'tcumhur bil-fikri's-sakıb), and "perfects the public affairs of mankind with his sound judgment" (mütemmimu mehami'l-enam bir-reyi's-saib). Immediately afterwards, however, Bayram Paşa's innate compassion is praised, and his compassionate character is cited as a natural disposition evidencing itself in sincere convictions of his heart marked by boundless compassion and clemency. ${ }^{55}$ Evident in the titles of rulers and political elites, compassion was regarded as an innate feeling and a bodily disposition, with an understanding that rulers are selected on the basis of having such a disposition. Yet, it was also believed to be an emotion that could and should be nurtured; hence, moralists always advised rulers to act compassionately toward their subjects, transforming the emotion of compassion into practice. As Monique Scheer has evidenced, ${ }^{56}$ in conformity with neuroscientic research, "emotions are practices themselvesan emotion is not something that happens to us but something that we do." Feeling compassion, accordingly, demands one to act compasionately.

Similar appraisals and titles are abundant in Ottoman primary sources regarding rulers, their agents, and even the palace itself as a reflection of Ottoman sovereignty. For example, in the introduction of his chronicle Raşid Tarihi, Raşid Efendi (d. 1735), who wrote the history of the Ottoman Empire for the period 1660-1729, praised the appointment of Damat İbrahim Paşa, the grand vizier (1718-30) during the reign of Sultan Ahmed III (1703-30), with special emphasis on commemorating his compassion and benevolence as well as his execution of the rules of tenderness and generosity. ${ }^{57}$ It seems plausible to claim that the display of love, as we have seen in the previous section, and the display of compassion by the Sultan and his delegated agents to subjects seem to reflect the emotionology of statecraft in the early modern Ottoman political context. Likewise, the Ottoman palace was referred to in the documents as a refuge of the universe (atebe-i aliyye-i alem-penah), a threshold of felicity (südde-i seniyye-i saadet-destgâh), which denoted not only a desire for universal sovereignty but also a promise of happiness for the Sultan's subjects. There was likewise frequent reference to the emotional well-being of those who had accepted Ottoman sovereignty and thus pursued a happy and prosperous life

55 "Bayram Paşa'nın cibilliyet-i zat-ı merhamet-nihad ve esniyye-i murad-ı fuadi'l halisi'litikadında asar-ı merhamet ve ref'et mevzu' olub." İnalcık, “Adaletnameler," p. 143.

$5^{6}$ Scheer, Monique, "Are emotions a kind of practice (and is that what makes them have a history)? A Bourdieuan approach to understanding emotion," History and Theory, 51/2 (2012), 193-220.

57 "ayin-i merhamet ü mürüvveti ihya ve kavanin-i şefkat ve fütüvveti icra.” Özcan, Abdülkadir et al., Tarih-i Raşid ve Zeyli Raşid Mehmed Efendive Çelebizade İsmail Asım Efendi (10711141 / 1660-1729), vol. I (Istanbul: Klasik, 2013), pp. 8-9. 
under the protection of the Sultan, reflecting the emotional constraints imposed to achieve political order. ${ }^{58}$

Although such praiseworthy titles in Ottoman official documentation may be regarded as either formulaic or state centered, replete with stock phrases, they are still illuminating tools by which we can discover not only the complex layers of meaning-making mechanisms but also the changing emotion codes through time. Indeed, the emotion codes of early modern societies for which the state was personified in the rulers' body, denoting a unification of the State with the Sultan, differed significantly from the emotion codes of modern societies where the notion of nation serves as an abstract entity. ${ }^{59}$

Imperial decrees also provide tools for historians to explore how the symbolic code of protection and its accompanying emotion code of compassion were duly practiced in the political negotiations of historical actors and thus were more than mere rhetoric. In such cases, we may follow the sequential link from the expression of the emotion of compassion to acting compassionately in daily politics. We frequently encounter the phrase "out of compassion for their condition" (hallerine merhameten) in state documents.

In some cases, this phrase reflects the pity of the ruler for the suffering or pain of one of his subjects. For example, in a sultanic order dated 1778 , it is ordered that a military officer (dergâh-ı mu'allâm cebecileri çorbacılarından ikinci cema'atin çorbacısı), Seyyid Mehmed Sâdık, whose leg was broken when he fell off a horse, be brought to Istanbul for treatment. ${ }^{60}$

$5^{8}$ "şimdiye değin dergah-ı saadet-destgahımıza istikametle tarik-i ubudiyyetin sabit-kadem olanlar enva'ı riayet ve inayetimizle hoşhal ve saye-i saadetimizde müreffehü'l-bal olub...” Kurat, Akdes Nimet, Rusya Tarihi: Başlangıçtan 1917'ye Kadar (Ankara: Türk Tarih Kurumu, 2014). Quoted from mühimme defteri no XVI, document 3:3-4.

59 For a different opinion on the separation of state from the ruler see Rifa'at 'Ali Abou-ElHaj, Formation of the Modern State: The Ottoman Empire, Sixteenth to Eighteenth Centuries (Syracuse, New York: Syracuse University Press, 2005), pp. 65-66. Abou-El-Haj argues that "as early as the later sixteenth and seventeenth centuries, ... documents testify to a narrowing specialization of functions within the Ottoman central administration ... that specialization of function preceded the tanzimat by several centuries." Although there were signs of separation between the state and the ruler, with increased specialization in bureaucracy by the mid seventeenth century, I still think that it should be regarded as a transitional period. Up until the advent of modernity (the Tanzimat reforms), for example, all the imperial decrees, personal orders of the Sultan, continued to be written as if they were direct words of the ruler, and any correspondence with the state was addressed to the Sultan only. The wording of the fermans and berats is as if the Sultan listened to all the discussions in the Imperial Council and he himself settled or redressed the issues.

6o "Bundan akdem İsmâil ser-askeri maiyyetine me'mûr dergâh-ı mu'allâ'm cebecileri çorbacılarından ikinci cema'atin çorbacısı Seyyid Mehmed Sâdık zîde kadruhû hidmet-i lâzımesinde kıyâm ve bezl-i makdûr üzre iken bi-gazâ'illâhi teâlâ atdan düşüb bir bacağı 
But more importantly, we trace several cases in which the ruler, in response to his subjects' demand for compassion (istida-yı merhamet), issues orders either to forgive subjects, change the terms of a previously determined punishment, or make the traditionally implemented practice more flexible.

A sultanic decree dating from the late sixteenth century ${ }^{61}$ provides evidence that the Sultan, with his compassion accompanying the symbolic code of protection of his subjects, could change the law. This does not denote, however, an arbitrary use of power, once we consider the emotion codes. According to this decree, previously both the sons and daughters of shop and cellar owners had the right to inheritance, which enabled orphans to use the rent of shops and cellars as their allowances. However, waqf administrators were ordered that only the sons of the deceased would be entitled to inheriting shops and cellars. The owners of those shops (ahali-i dekakin) and craftsmen (erbab-ı hiref) had

şikest olub bir istinâd-ı sınıkcı olmadığından üç mâhdan berü zahmi müşted ve ... ve mahall-i mezkûrda kalır ise telef-i nefs olacağını zâbitân-ı ocak tarafından inhâ olunmakdan nâşî mûmâileyhin hâl-i perişânına merhameten Astâne-i aliyye'me gelüb hânesinde bir hâzik sınıkcı ve cerrâh ile devâ ve illetinden halâs oldukda yine hidmet-i me'mûre azîmet etmek üzre Der aliyye'me gelmesine müsâ‘ade-i aliyyem erzân kılınmış Dergâh-ı mu'allâ'm kapucubaşılarından olub hâlâ cebecibaşı olan Şa'bân Ağa dâme mecduhû i'lâm etmeğin vech-i meşrûh üzre amel olunmak fermânım olmağın imdi sen ki vezîr-i müşârün-ileyhsin mûmâ ileyhin hâl-i ızdırâbına merhameten Astâne-i aliyye'mde illetine ba'de'l-müdâvâ ve's-sıhha mahall-i me'mûresine gelmek üzre Der aliyye'me vürûduna izn ü ruhsat-ı şâhânem erzân kılındığı ma'lûmun oldukda ber minvâl-i muharrer mûmâ ileyhin Der-saâdet'üme ircâ‘'na mümâna'at olunma(ma)k bâbında...” Özbay, Kadir, "177 numaralı Mühimme Defterinin transkripsiyon ve tahlili (H.1192-1193/M.1777-1778)" (unpublished M.A. thesis, Yüzüncü Yll Üniversitesi, 2008), p. 241.

61 "Yenişehir kâdîsına hüküm ki: Taht-ı kazânda olan erbâb-ı hıref ve ahâlî-i dekâkîn Âsitâne-i Sa'âdet-âşiyânuma âdem gönderüp; bundan akdem kendü mâllarıyla kârgîr dekâkîn ü mehâzin binâ itdürüp veyâhûd akça ile satun alup vefât eyledüklerinde oğullarına ve kızlarına intikâl idüp eytâma sebeb-i ma‘âş olurdı. Ba‘dehû; kızlara dükkân ü mahzen virilmeye diyü mütevellîlere ahkâm virilmekle hâl-i hayâtlarında mâ-meleklerin dekâkîn ü mehâzine virenler vefât eyledüklerinde yetîmeleri şiddet-i ihtiyâc ile muhtâc ü zelîl oldukların bildürüp; kızlarına virilmek bâbında istid'â-yı âtıfet eylemeğin mezîd-i merhametümden işbu sene: 978 Cemâziye'l-ûlâsı'nun sekizinci güninden kızlarına dahı virilmek emridüp buyurdum ki: Hükm-i şerîf-i vâcibü'l-ittibâ‘um vardukda, emrüm üzre evkâfa müte‘allik dekâkîn ü mehâzinün eger kârgîr binâlarıdur ve eger gayridür; anun gibi müste'cirleri vefât eyledüklerinde oğullarına ve kızlarına icâre-i mu'ayyene-i câriye ile virdürüp mütevellîleri ol bâbda dahl ü ta'arruz itdürmeyüp müste'cirlerden fevtolup evlâdı kalmayanlarun dekâkîn ü mehâzini ve sâyir evkâfa müte‘allik yirleri muktezâ-yı şer'-1 şerîf üzre vakıf tarafından mütevellîlere zabt u kabz itdürüp şer'-1 şerîfe muhâlif hâricden kimesneyi dahl itdürmeyesin ve bu emr-i şerîfümi sicill-i mahfûza kayditdükden sonra ellerinde ibkâ eyleyesin ki, dâyimâ mazmûn-ı hümâyûnı ile amel oluna, şöyle bilesin..." 12 Numaralı Mühimme Defteri (978-979/1570-1572) (Ankara: Devlet Arşivleri Genel Müdürlüğü, 1996), p. 171. 
sent their agents acting on their behalf and officially requested (istida') mercy (attfet) from the Sultan to change this rule and allow daughters to have the right to inheritance, contending that the daughters had become extremely needy and were treated with contempt (zelil) after their fathers' death. Based on their petition, the Sultan, expressing his compassion for the condition of the orphaned daughters (hallerine merhameten), ordered that the rule be changed accordingly.

According to another imperial decree dating from the late eighteenth century, the Sultan granted timars as a source of revenue to slaves of the Porte (kapıkulu); regulations strictly demanded that these slaves provide service to the Sultan in his palace in times of peace and join the Sultan's expeditions in times of war. The practice of settling and residing in the granted units of taxation and administration, however, became so widespread for the kapıkulus that it had become difficult for them to obey the current regulation of returning to the palace once a war was over. Despite the fact that the law was against such a practice, the Sultan, out of compassion for their condition and in quest of a favorable solution in response to their requests, used the emotion code of compassion to legitimize an order permitting his slaves to serve in the palace for six months and to live in their settled homes for the remaining six months of the year. ${ }^{62}$

Likewise, another imperial decree dating from the early eighteenth century ordered that the timar and zeamet holders, who were then in the service of the vizier Mustafa Paşa for the protection of the fort of Gence, be pardoned and allowed to return to their vilayets (although vilayet literally means province, here it denotes the timar and zeamet holders' homes, where they lived), units

62 “... malum ola ki, Rumilinde ve Anadolu'da zeamet ve tımara mutasarrıf olan gedüklü Dergâh-ı Ali müteferrikaları ve çavuşları ve Divan-ı Alişan ve Defter-i Hakani kâtipleri ve şakirdleri; an-asl seferlerde vezir-i azamlar ile sefer eşüb, ve hazarlarda Der-i devletmedarda zabitleri marifetiyle daima hidmette mevcud bulunmak üzere mevzu' olub, hatta yedlerine verilen nişan-ı alişanda ale'd-devam Divan-ı Ali makam hidmetinde bulunalar deyü meşruh ve mestur iken bu kaidenin riayetinde adem-i ihtimamdan naşi zümre-i mezbureden bazıları taşralarda zeamet ve tımarları olduğu yerlerde ve sair istedikleri mahallerde tavattun ve temekkün itmeleriyle esna-i hazarda kanun-ı kadime riayet etmeyüb, ... ancak mezburların her biri taşralarda alaka hasıl etmeleriyle hallerine merhameten evlerinde ve yerlerinde külliyet ile mehcûr olmayıb, kanun-ı kadim dahi bil'l-külliye terk olunmayı fi'l-cümle mer'i olmak üzere taife-i mezbureden Rumili ve Özi eyaletlerinde mutavattın olanlar her senede altı ay ve Anadolu'da ve eyalet-i sairede mutavattın olanlar dahi beher sene altı ay münavebe tarikiyle gelüb, Asitane-i Saadetimde zabitleri marifetiyle iktiza iden hidemat-ı aliyyede bulunmak üzere bundan akdem şerefyafte-i sudûr olan evamir-i şerîfem mucebince Rumili ve Özi eyaletlerinde olanlar müsillü sair yerlerde sakin olan gedüklüler için dahi fermanım sadır olmuşdur." I would like to thank Özer Ergenç who gave me permission to use this source from his personal archive. 
of taxation and administration from which they drew their income. Although timar holders were required to serve in expeditions, they made a political claim to be allowed to return to their homes based on their suffering as a result of being away from their families for four to five years. A change in the current rule was thus made, not only bringing flexibility into this practice but also legitimizing the new version of the rule through reference to the emotion code of compassion (hallerinize merhameten). ${ }^{63}$ The compassion of the Sultan in such cases was used as a tool to legitimize changes in current rules and regulations regarding the Sultan's delegated agents.

The continuity in the expected display of compassion by the Sultan as a part of emotionology is apparent even in cases dating from the early nineteenth century. For example, an imperial decree of 1828 was issued with respect to an Armenian woman in Kumkapı, Istanbul, who worked as a midwife. ${ }^{64}$ The woman had previously performed some illegal acts, such as the termination of pregnancies without consent [of society] (hilaf-ı rlza), and therefore had been

63 'Sivas Eyâleti'nin elviye alaybeylerine hüküm ki: Birkaç seneden berü düstûr-ı mükerrem müşîr-i mufahham nizâmu'l-âlem hâlâ Gence muhâfızı vezîrim Mustafa Paşa edâmallâhu teâlâ iclâlehûnun ma'iyyetinde iktizâ iden hidemât-ı dîn ü devlet-i 'aliyyemde sancaklarınızın zü'emâ ve erbâb-ı tîmârlarıyla bezl-i tâb ü tüvân eyleyüb ve hâlâ hallerinize za'f târî olmağla vilâyetlerinize izin ve ruhsat virilmek üzere vezîr-i müşârun ileyh tarafından 'arz ve i'lâm olunub fi'l-hakîka dört beş seneden berû ehl ü 'yyâlinizden dûr ve hidemât-ı 'aliyyede tahsîl-i rızâ-yı hümâyûnum içün bezl-i makdûr itmeniz ile sa'yleriniz mebrûr ve meşkûr olmağla hallerinize merhameten vilâyetlerinizi 'avdete izn-i hümâyun erzânî kllınmışdır imdi işbu emr-i şerîfim ile vüsûlünde vezîr-i müşârun ileyhin ma'rifetiyle bi'l-cümle sancaklarınızı zü‘emâ ve erbâb-ı tîmârıyla vilâyetlerinize 'avdet eylemeniz bâbında fermân-ı 'âlîşânım sâdr olmuşdur, buyurdum ki..." Kurt, Zeynep, "13 numaralı ve 1727-1730 tarihli Mühimme Zeyli Defteri (değerlendirme-transkripsiyondizin)" (unpublished M.A. thesis, Firat Üniversitesi, 2005), p. 186.

64 “... Kumkapıda mütemekkin ermeni gariplerinden Küpeli ebe iskât-ı cenin misüllû hilaf-ı rıza harekete ictisal eylediğine mebni bundan akdem sadır olan emr-i şerifim mucibince li-eclü't-te'dib Kütahyaya nefy ve icla olunmuş ise de mersûmenin nefy tazi hayli müddet olarak fukara ve ihtiyarlık sebebiyle müzdarib ve perişan ve vucuh-ı merhamet ve şefâate şayeste ve şitayan olduğundan bahisle afv ve ıtlak olunması hususu mersumenin zevciyle kızı taraflarından bu defa südde-i saadetime arzuhal takdimiyle istirham olunmaktan nâşi hususu mezbûr seredi bayı hassamdan olan Rum ili kazaskeri esbak a'lâmü'l-ulemâi'lmütebahhirin mevlânâ Mustafa Behçet edamallahü teala fezâilehûya havâle olundukta mersume adeti reddiyeye sabıkasından vucuh ile kabil terbiye olduğu tahkik gelindiği beyanıla ıskat-ı cenini hımarından fima ba‘d kefyed ve feragat ile sanatında arzıyla meşgul olmak ve ba‘de'l-yevm iş bu kar-ı şer‘ eylediği mesmu olunduğunda te'dibinde diğer vecihle muamele olunmak şartıyla merhameten afv ve ıtlakı babında emri şerifim suduruna hâvi ilâm etmekle ilâmı mucibince mersumun afv ve ıtlak olunması fermanım olmağın..." Yavuz, Mustafa, "Kütahya şer'iye sicilleri 15 numaralı defterinin transkripsiyonu ve değerlendirilmesi" (unpublished M.A. thesis, Dumlupınar Üniversitesi, 2009), p. 111. 
expelled to Kütahya to be disciplined. Pregnancy termination was illegal as per Islamic law, and it was also considered an act against social norms. The midwife had lived in Kütahya for a long time, suffering from her defenselessness and old age (hayli müddet olarak fukara ve ihtiyarlık sebebiyle muzdarib ve perişan). The daughter of the midwife appealed to the Imperial Council, asking that her mother be forgiven and released. We may infer from her request that she believed that her mother had already paid for her crime by living in Kütahya for a long time and that she needed to be protected because of her old age and thus deserved the right to apply for the compassion of the Sultan. The midwife was pardoned, as it was believed that she had renounced her previous evil practice (adet-i reddiye-i sabıkasından rücû) and was determined to perform her profession in an honorable way (san'atında trzıyla meşgul olmak). In the Sultan's order, it was emphasized, however, that she had been forgiven "out of [the Sultan's] compassion [for her condition]" (merhameten afv). Compassion, in this case, may also be interpreted as a consideration of the proportion between crime and punishment.

According to another decree of 1828, the mufti of Aydın was also banished to Kütahya as a punishment for having acted without consent [of society] (hilaf-ı rıza). ${ }^{65}$ His wife, children, and other family members officially sought the Sultan's pardon, asking for his mercy. They based their request on their father's good behavior from the first day of his banishment and on their desolate and wretched conditions because of their father's absence. The mufti was pardoned, as his family had also been indirectly penalized for his crime, and similar to the case above, the Sultan's pardon was legitimized by the phrase "out of [the Sultan's] compassion [for the condition of the mufti of Aydın]" (merkumun merhameten afv).

The examples cited cover a long time frame from the late sixteenth to the nineteenth century. As has been pointed out, the legacy of ancient and preOttoman tradition is apparent in Ahlak-i Ala $i$. Likewise, several concepts and metaphors in the archival documents reflect a long tradition in shaping the style and form of these documents. For example, as we have discussed, all the documents are written as if it is the ruler speaking, and petitions with political

65 "Kütahya nâibi mevlânâ zide ilmuhû tevki-i refi-i hümayun vasıl olucak malûm ola ki bundan akdem Aydın kazasında mezunen bi'l-ifta olan hilaf-ı rıza hareketi ibtidarına mebni Kütahyaya nefy ve icla olunan Ahmed Rafiin mütteti nikaından beri memleketinde olan iyi hali ve evladı bi-kes ve perişan kalarak vucuhla merhameten şayan olduklarından bahisle merkumun afv ve itlakı hususuna müsaade-i aliyyem erzan kılınması iyi hal ve evladı taraflarından arzuhal takdirleriyle istida istirham olunmaktan naşi merkumun merhameten afv ıtlakı babında emr-i şerifim suduruna..." Yavuz, "Kütahya şer'iye sicilleri", p. 101. 
claims are always personally addressed to the Sultan up until the mid nineteenth century. Likewise, the terms and concepts related to emotions, as in hallerine merhameten, are cited in exactly the same way in this long period between the sixteenth and the mid nineteenth centuries. Only then can we see a change in the style of archival documents. It thus seems plausible to claim that norms regarding when, how, and to whom to express compassion did not radically change until the mid nineteenth century.

Although it does not literally denote any emotions, the phrase evla ve enfa, which refers to what is most suitable and most beneficial, is similar in function to "out of [the Sultan's] compassion for his/her condition" and was frequently used as a tool to legitimize the implementation of rules and regulations. Evla ve enfa was first analyzed by Özer Ergenç, who has pointed out that although it was commonly used in state-subject relations, it was also used as a tool for the settlement of disputes that concerned the relations between individuals and society. This was particularly so in waqf-related conflicts and also in cases regarding the rules implemented for individuals in need of protection, such as a sabi (male child) or a pir (old man). ${ }^{66}$ Ergenç argues that the expected functions of this concept were threefold. The first was finding the most beneficial solution, the second was amicably resolving a conflict, and the third was legitimizing the resolution. ${ }^{67}$ Especially in waqf-related cases, even though the decision taken could be against the written and certified will of a founder of a waqf, the use of the phrase "most suitable and most beneficial" was used as a tool to legitimize a seemingly arbitrary decision.

Compassion, as evidenced by the documents discussed above, served as an emotion code indicating a shared understanding of when, how, and in which cases it was appropriate for rulers to express compassion and to translate this expression into action in order to sustain order and ensure the rulers' legitimacy. There were also well-understood conventions as to when it was appropriate for subjects to display discontent and ask for compassion. These displays of discontent and the linguistic representations of such displays were reflected in imperial decrees issued in response to subjects' political claims, making it also possible to hear the voices of subjects. The subjects' demand for compassion in the cases analyzed represents their changing perceptions of the Sultan, who, as a just and legitimate ruler, was expected to protect his subjects with compassion. Likewise, the imperial orders were issued in reply to such requests

\footnotetext{
66 Ergenç, Özer, “Osmanlı'da enfa kuralının devlet ve reaya arasındaki mali ilişkiler açısından anlamı," in Idem, Osmanlı Tarihi Yazıları Şehir, Toplum, Devlet (Istanbul: Tarih Vakfı Yurt Yayınları, 2012), pp. 429-42.

67 Ibid., p. 432.
} 
and represent the Sultan's effort to reverse the subjects' perception and to legitimize his rule.

Political claims of the subjects are usually cases in which perceptions of protection conducted in the proper way had deteriorated, with subjects losing their emotional (müreffehül-bal) and material prosperity (asude-hal) and entering a state of being dispersed and scattered (perakende ve perişan). The symbolic code of protection was no longer perceived to accompany the emotion code of compassion, representing a detachment of the emotion codes from symbolic codes. Subjects, then, would usually demand a change. While doing so, however, they would refer to the commonly shared symbolic and emotion codes, which would enable them to justify their claims. ${ }^{68}$ The subjects' demands for compassion also functioned as social signals, implying that the Sultan's legitimacy as a protective ruler was in danger, thus requiring the Sultan to take political action. The strategic use of emotions in the political language thus helped both parties attain their short- or long-term political goals.

\section{Conclusion}

This article has taken a closer look at familiar sources of Ottoman history and questioned the role of the emotions of love and compassion in early modern Ottoman political language. It aims to give a more plausible explanation of why political actors acted the way they did. In this quest, this study has used the symbolic and accompanying emotion codes as an explanatory model.

It has been shown that mutual love in political relations and the symbolic code of protection, with its accompanying emotion code of compassion, were the main themes of Ottoman political thought in the early modern era. As an answer to the question about what love has got to do with politics, this study has shown that the emotions of love and compassion were not only regarded as private and innate but also as social and political, each having its own norms as to when, to whom, and how it should be displayed, as well as acting as a tool to formulate political relations of domination and subordination.

The linguistic expressions of compassion leading to specific political actions further evidence that the display of compassion legitimized the political

68 See, for example, a sultanic decree copied in the kadı court records of Edirne in the mid eighteenth century: "vakf-ı mezbur mürtezika fukaralarına gadr-i külli olduğu tarafımıza arz ve mahzar birle ilam ve istida-yı merhamet itmeleriyle..." (with their petition to us, they asked for compassion reporting that they suffer oppression...). Samıkıran, Oğuzhan, "138 numaralı Edirne şer'iyye sicili H.1119-1161/M.1707-1748" (unpublished M.A. thesis, Firat University, 2006), p. $65^{2}$. 
undertakings of Ottoman rulers and may therefore serve as an explanation to seemingly arbitrary undertakings. Likewise, the subjects' demand for compassion justified their political claims.

The emotion code of compassion was culturally and historically significant during the period between the sixteenth and the nineteenth centuries, when it was compatible with the personification of the state in the body of the ruler. Starting with the culmination in the sixteenth century of a gradual process of institutionalizing traditional systems, the Ottoman state formulated its political language as a claimant of universal sovereignty, with embedded emotion codes that were collectively shared in the mutual process of legitimization and that remained so until the period of reforms (Tanzimat) in the mid nineteenth century. In its essence, modernization in that period represents an attempt to reconfigure ruler-subject relations. It mainly consists in the de-personification of the state and its transformation into an abstract entity, thus leading also to a change in commonly shared emotion codes.

Despite their frequency as a reference in primary sources, however, the choice of emotion words for conceptualization in this study may not fully represent the emotional standards of early modern Ottoman society; this work should be regarded as a preliminary one that therefore necessitates further research. Sources also evidence anger, envy, disgust, and fear in cases in which the political relations had deviated from their idealized forms. However, these emotions are not within the scope of this article and certainly have to be explored once Ottoman historians welcome the claim that emotions need to be historicized.

\section{Acknowledgements}

This article is based on the findings of the author's doctoral dissertation titled "A gate to the emotional world of pre-modern Ottoman society: An attempt to write Ottoman history from 'the inside out"' (unpublished Ph.D. dissertation, Ankara: Bilkent University, 2016). I would like to thank Özer Ergenç for his supervision and critical remarks throughout my research and to Cemal Kafadar for his insightful comments on earlier drafts of this manuscript. My sincere gratitude is due to the anonymous reviewers and the editors of Turkish Historical Review for their thoughtful comments and suggestions which helped to me to form this final version. 